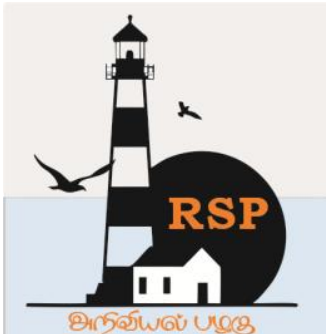

INTERNATIONAL RESEARCH JOURNAL ON ADVANCED SCIENCE HUB

(The Hub of Research Ideas)

Available online at www.rspsciencehub.com

Special Issue of Second International Conference on Innovation in Engineering Sciences (ICIES2021)

\title{
Soil properties of medium land rice (Oryza sativa L.) in inorganic nitrogenous fertilizers on fym combination in yield
}

Himanshu sekhar beheral, Bijoy kumar pany ${ }^{2}$

${ }^{1}$ Research scholar, School of agriculture, Lovely professional university, Punjab, India.

${ }^{2}$ Professor, HOD, Dept. of soil science and agricultural chemistry, Institute of agricultural science, Siksha "o" Anusandhan university, Bhubaneswar,Odisha, 751030

himanshubeherars4@gmail.com ${ }^{1}$

\begin{abstract}
A pot culture experiment entitled "soil properties of medium land rice (Oryza sativa L.) in inorganic nitrogenous fertilizers on fym combination in yield." was conducted at Institute of Agricultural Sciences farm of Siksha 'O' Anusandhan (Deemed to be University), Bhubaneswar Odisha on sandy loam soil during kharif 2018-2019. The experiment was planned in a Randomized Block Design with three replications and comprised eight treatment such as T1-Control, T2-50\% Recommended dose of fertilizer (RDF),T3-50\% RDF + 5t FYM per ha-1, T4-75\% RDF, T5-75\% RDF + 5t FYM per ha-1, T6- 100\%RDF ( NPK 80:40:40), T7-100\% RDF + 5t FYM per haland T8-150\% RDF. Similar inclination were observed on yields of grain, straw and values of different growth parameters at different level of nitrogen and their combination with 5t FYM per ha-1 but at $150 \%$ RDF level, the values of different parameters including grain and straw yield were significantly low as compared to the treatment that received $100 \%$ $R D F+5 t$ FYM per ha-1. Grain and straw analysis recorded higher N, P, K content by use of 100\% RDF $+5 t$ FYM per ha-1 as compared with $100 \%$ and $150 \%$ RDF alone. physio-chemical conditions of soil like bulk density, porosity, organic carbon, available macro nutrients $(N, P, K)$ were improved with the joint application of $100 \%$ RDF as inorganic source with 5t FYM per ha-las organic source. In this present study it can be resolved that in Odisha soil (sandy loam) joint application of $100 \%$ mineral nitrogen and 5t FYM per ha-1 enhanced availability of macro nutrients, better physical environment and produced significantly low yields with application of $150 \%$ RDF as compared to treatment combinations with inorganic fertilizer and FYM and almost equal yield with the recommended dose of nitrogen (100\% RDF) only in mineral form.
\end{abstract}

Keywords: Inorganic nitrogen, FYM, plant growth and yield, yield attributing characters, Integrated nutrient management

\section{Introduction:}

The most vital cereal crop rice is an essential food for greater than $70 \%$ of the population of the world. . In India rice is the most important staple food, contributing $45 \%$ to the total food grain production. Increasing demand for rice is noticed in India as population of India is increasing at an alarming speed, the projected estimate is 1.378 billion by 2030 which may rich 1.67 billion by
2050 there by increasing population more than $22 \%$. Area wise India occupies first position (44.50 million ha) and production wise it is second 102.75 million tonnes as compared to China but it has very low productivity i.e. 2.20 tones ha1.Odisha state located in the $17^{\circ} 31^{\prime}-22^{\circ} 27^{\prime}$ north latitude and $81^{\circ} 27^{\prime}-87^{\circ} 30^{\prime}$ east longitude of eastern India. The gross cultivated area and the total area under food grain occupies $69 \%$ and $63 \%$ 
respectively of the total area of Odisha. Rice is cultivated in 4.18 million ha and the anual production is 7.58 million tonnes with average yield of $1815 \mathrm{~kg}$ ha-1 in Odisha. Productivity of Odisha soil are mainly constrained by iron (Fe) and aluminium (Al) toxicity, phosphorus (P) deficiency, low base saturation, low microbial activity, and other acidity induced problems. Nitrogen $(\mathrm{N})$ is one of the main factors affecting rice yield and low nitrogen recovery by the crop under such problematic soils call for a sustainable approach of managing nitrogen for increasing the yield as well as improving its use efficiency. Puli et al.,2017 reported application of both inorganic and organic fertilizers in combination can manage the soil fertility to a greater extent as mineral fertilizer provides nutrients and the organic fertilizers improves soil organic carbon, soil structure, water holding capacity and buffering capacity of the soil. Rice plants depends upon the organic pool of the soil for its nitrogen but the organic pool contains very low amount of nitrogen.[1-7].

\section{Materials and Methods}

The study was taken in earthen pots at Research farmhouse, Campus-4, Institute of Agricultural Science, Siksha 'O' Anusandhan (Deemed to be University), Bhubaneswar, Odisha during Kharif 2018-2019. Soil collected from experimental site. The experiment consisted of eight treatments viz. T1-Control, T2- 50\% RDF, T3-50\% RDF + FYM @ 5t ha-1, T4-75\% RDF, T5-75\% RDF + FYM @ 5t ha-1, T6- 100\% RDF ( NPK80:40:40), T7100\% RDF+FYM @ 5t ha-1 and T8-150\% RDF. The experiment was arranged in RBD (Randomized block design) by means of three replications. Four hills @ two rice (30 days old) seedlings per hill of variety Naveen (120 days duration) were transplanted in each pot. Well decomposed farmyard manure (@ 5t ha-1) with $0.5 \%$ nitrogen, $0.2 \% \mathrm{P}$ and $0.4 \% \mathrm{~K}$ was added to pots as per treatment 7 days before transplanting of rice on dry weight basis as organic source. Soon after completion of transplanting a water level of 2 to $3 \mathrm{~cm}$ depth maintained in each pot till panicle initiation stage thereafter water was drained out to provide good aeration to plants and subsequently water refilled in the pots equal to initial depth of water up to physiological maturity. After dough stage pots were drained out to enable relaxed harvesting. Plant height at 30,60 and 90 DAT (Days after transplanting) and at harvest, entire number of tillers per hill at 30 and 90 DAT, total count of ear bearing tillers at maturity, length of panicles, quantity of grains per panicle, 100 seed weight, straw and grain yield were recorded following standard procedures. The collected plant and soil samples from each pot after harvest were processed and analysed for different nutrient uptake in grain and straw and soil parameters following standard procedures.[4-7].

\section{Results and Discussion}

The physical and chemical properties of the soil used in pots was analysed following standard procedure. The soil was acidic in reaction $(\mathrm{pH}$ 5.65), Electrical conductivity (EC $0.58 \mathrm{dSm}-1)$ non saline, sandy loam (Clay $9 \%$, Silt $21 \%$, Sand 70 $\%$ ) in texture. The Bulk density of soil was 1.58 $\mathrm{g} / \mathrm{cc}$ and particle density of was $2.64 \mathrm{~g} / \mathrm{cc}$. The moisture content of soil was 26 percent. The Cation Exchange Capacity of the soil was $5.8 \mathrm{~mol}$ $\mathrm{P}+\mathrm{kg}^{\mathrm{k}} 1$ of soil. The soil was low in organic carbon $58 \mathrm{~g} \mathrm{~kg}-1$, and in available nitrogen $245 \mathrm{~kg}$ ha- 1 whereas medium in phosphorus $13.2 \mathrm{~kg}$ ha1and potassium $156 \mathrm{~kg}$ ha-1.The results of different parameters of the experiment were analysed statistically with the help of computer following the MSTAT procedure for randomize block design (RBD) with critical difference (CD) at 5\% and standard error of means as suggested by Cochran and Cox 1977. The present research findings were discussed on the basis of reason, properties and corroborative research findings of the scientists.

\section{Yield Attributes}

Results of most yield attributing characters of rice namely panicle number per hill, length panicle $(\mathrm{cm})$, total grains panicle-1, sterile grain panicle-1, grain filling\%, test weight were discussed. It was found that all the yield components were significantly influenced by the application of inorganic nitrogenous fertilizers and farmyard manure combinations and doses of nitrogen. Discrete positive effect of inorganic nitrogenous fertilizers alone at 50, 75, 100, 150\% RDF level and the combination with 5t ha-1 FYM in the first three levels RDF was noticed on these yield attributes. Panicle length was highly significant for different nitrogen doses and their combinations with FYM. The highest panicle length $27.16 \mathrm{~cm}$ was found in T7(100\% NPK + 5t FYM ha-1) and 


\section{www.rspsciencehub.com}

the lower most panicle measurement $(20.78 \mathrm{~cm})$ was observed in T1 (control). Results showed that length of panicle enlarged through the rise in nitrogen rate. Nitrogen plays vital role in panicle formation and elongation due to which length of panicle increased by means of intensification of nitrogen fertilization. All yield attributing parameters attained higher values with increasing NPK level from unfertilized to $150 \% \mathrm{RDF}$ and further when FYM was applied at the rate of $5 \mathrm{t}$ ha1 in combination with 50, 75 and $100 \%$ RDF brought about appreciable increase in yield attributing characters due to slow release and constant stream of nutrients in balance amounts throughout the development phases that permits the rice plants to integrateadequate photosynthetic products. Hence, resulted in the production of increased panicles with a greater number of fertile

Table.1. Impact of inorganic nitrogenous fertilizers and farmyard manure on yield characteristics of rice.

\begin{tabular}{|c|c|c|c|c|c|c|c|}
\hline Treatments & $\begin{array}{c}\text { No of } \\
\text { Panicles } \\
\text { per hill at } \\
\text { harvest }\end{array}$ & $\begin{array}{l}\text { Panicle } \\
\text { length } \\
(\mathrm{cm})\end{array}$ & $\begin{array}{c}\text { Total } \\
\text { grains/ } \\
\text { panicle }\end{array}$ & $\begin{array}{c}\text { No of } \\
\text { filled } \\
\text { grains/ } \\
\text { panicle }\end{array}$ & $\begin{array}{l}\text { Sterile } \\
\text { grains/ } \\
\text { panicle }\end{array}$ & $\begin{array}{c}\text { Grains } \\
\text { filling } \\
\%\end{array}$ & $\begin{array}{c}\text { Test } \\
\text { weight } \\
\text { (g) }\end{array}$ \\
\hline T1- Control & 6.00 & 20.78 & 109.33 & 88.00 & 21.33 & 80.48 & 19.56 \\
\hline $\mathrm{T} 2-50 \% \mathrm{RDF}$ & 6.67 & 22.90 & 114.67 & 96.67 & 18.00 & 84.30 & 20.76 \\
\hline $\begin{array}{l}\text { T3 -50\% RDF } \\
+\mathrm{FYM} @ 5 \mathrm{t} / \mathrm{ha}\end{array}$ & 7.33 & 23.32 & 124.33 & 108.67 & 15.67 & 87.41 & 21.78 \\
\hline $\mathrm{T} 4-75 \% \mathrm{RDF}$ & 9.33 & 24.55 & 132.33 & 114.67 & 17.67 & 86.66 & 21.86 \\
\hline $\begin{array}{l}\text { T5 }-75 \% \text { RDF } \\
+ \text { +FYM@ 5t/ha }\end{array}$ & 12.33 & 25.92 & 134.00 & 120.00 & 14.00 & 88.85 & 22.24 \\
\hline T6-100\% RDF & 14.33 & 26.14 & 141.67 & 122.67 & 19.00 & 86.67 & 23.16 \\
\hline $\begin{array}{l}\text { T7-100\% RDF } \\
+ \text { +FYM@ 5t/ha }\end{array}$ & 16.67 & 27.16 & 143.67 & 127.67 & 16.00 & 89.55 & 24.28 \\
\hline $\mathrm{T} 8-150 \% \mathrm{RDF}$ & 16.00 & 26.66 & 143.33 & 126.33 & 20.00 & 86.33 & 22.82 \\
\hline SEm \pm & 0.46 & 0.31 & 1.46 & 1.44 & 0.63 & 0.42 & 1.15 \\
\hline $\mathrm{CD}(\mathrm{P}=0.05)$ & 1.40 & 0.94 & 4.96 & 4.38 & 1.93 & 1.27 & NS \\
\hline
\end{tabular}

\section{Conclusion}

Use of 5t FYM ha-1 in combination through 100 $\%$ of RDF increased grain yield and yield attributing characters of rice due to increased nutrient availability and it also improved the soil physical, chemical and biological properties. Hence, the use of FYM 5t ha-1 with $100 \%$ (80:40:40NPK) RDF was found to be appropriate to improve productivity of rice and the physiochemical properties of the soil as matched to the grains. Significantly higher yield attributes (number of panicle, panicle length, filled grains panicle-1, grain filling \%) were recorded with T7 (100\% RDF + FYM @ 5t/ha) which remained at par with T8 (150\% RDF) and superior to other treatments including control. The result 2012 and Das et al., 2014. The data on test weight (1000- seeds) is existing in The upper most 1000 seed weight, $24.24 \mathrm{~g}$ was noted in $100 \% \mathrm{NPK}+5 \mathrm{t}$ FYM (T7) tracked by $23.16 \mathrm{~g}$ in $100 \%$ NPK (T6) and lowest (19.56 g) in control plot. There was no significant variation for weight of 1000-grains among various treatments. The little variation in test weight might be owing to alterations in grains size which were partly governed by hereditary makeup of the cultivar under study. corroborates with the findings of Kumar et al.,

use of $100 \%$ RDF only. Thus, use of mineral fertilizer together with Farm yard manure should be included in integrated crop management for sustainable agriculture.

\section{Acknowledgement}

We are very much thankful to Dean, Faculty of Agricultural Sciences, and Institute of Agricultural Sciences for providing laboratory facilities and the Farm Supervisor of Capus-4 Farm for providing necessary services to raise the crop. 


\section{References}

\section{Journals}

[1]. Alim MA. (2012). Effect of Organic and inorganic sources and doses of nitrogen fertilizer on the yield of Boro Rice. J. Environ. Sci. \& Natural Resources, 5(1): 273- 282

[2]. Aziz MA, Amees TA, Mahdi SS, Ali T (2012). Effect of integrated nutrient management on soil physical properties using soybean (Glycine max (L.) merill) as indicator crop under temperate conditions. International Journal of Current Research. 4(1): 203-207

[3].Buri MM, Lssaka RN, Wakatsuki $\mathrm{T}$ and Kawano N (2012). Improving the productivity of lowland soils for rice cultivation in Ghana: The role of the 'Sawah' system. Journal of Soil Science and Environmental Management 3(3): 56-62.

[4]. Cochran WG, \& Cox GM (1957). Experimental designs (2nd ed.). John Wiley \& Sons.

[5]. Das B, Chakraborty D, Singh VK, Aggarwal P, Singh R, Dwivedi BS and Mishra RP (2014).Effect of integrated nutrient management practice on soil aggregate properties, its stability and aggregateassociated carbon content in an intensive ricewheat system. Soil \& Tillage Research 136: 918

[6].FAO (2004). Special description of Oryza sativa. http;//www.fao. Org/ag/AGP/doc/BBASE/data/pf00274.htm.

[7]. Gour SP, Singh SK, Lal R, Singh RP, Bohra JS, Srivastava JP, Singh SP, Kumar M, Kumar $\mathrm{O}$ and Latare AM (2015). Effect of organic and inorganic sources of plant nutrients on growth and yield of rice (Oryza sativa) and soil fertility, Indian Journal of Agronomy 60 (2): 328-331. 